\title{
BANQUETE DE GENTE: COMENSALIDADE E CANIBALISMO NA AMAZÔNIA*
}

Carlos Fausto

Nosso corpo não é outra coisa que um edifício de almas múltiplas.

L'effet, c'est moi (F. Nietzsche, Além do Bem e do Mal).

Este texto é um ensaio no sentido estrito do termo: uma prosa que versa sobre um tema específico, sem esgotá-lo, reunindo idéias e dados de outros autores, de forma a ressaltar certas articulações ainda pouco exploradas. De maneira geral, ele trata da caça e da guerra na Amazônia e, em particular, focaliza a relação entre comensalidade e predação. Meu intuito é aproximar os estudos sobre predação guerreira daqueles sobre a fabricação do parentesco, tratando a predação e a comensalidade como formas distintas, mas dinamicamente articuladas, de produção de pessoas e da socialidade na Amazônia.

O ensaio é também uma tentativa de complementar idéias que restaram inexploradas em meu livro sobre os Parakanã, no qual procurei desenvolver um modelo da guerra e do xamanismo indígenas que articulasse a predação no exterior à produção no interior. Esse modelo focaliza sobretudo a produção ritual do interior - o rito enquanto momento da predação familiarizante — , deixando em segundo plano a produção cotidiana do interior, objeto privilegiado dos estudos da escola americanista britânica ${ }^{1}$. Detive-me, sobretudo, no momento dinâmico em que exterioridade e interioridade se definem como pólos de um mesmo movimento. Não enfrentei, porém, a questão de como pessoas apropriadas no exterior são efetivamente produzidas enquanto parentes. Em particular, não articulei, para usar o vocabulário marxiano, o consumo produtivo à produção consumptiva. No epílogo do livro, limitei-me a distinguir as atividades guerreiras e cinegéticas como duas formas de consumo: a primeira visando à produção ontológica de pessoas; a segunda, ao crescimento vegetativo do indivíduo (Fausto 2001:538). A distinção entre canibalismo e alimentação aparecia, assim, como equivalente àquela entre um consumo voltado para 
o desenvolvimento das capacidades subjetivas da pessoa e outro voltado para a produção do corpo físico.

Relendo hoje essa formulação, identifico nela duas insuficiências: de um lado, ela não explica como as duas formas de consumo se articulam; de outro, ela parece pressupor um dualismo simples e global entre corpo e alma. O objetivo deste texto é, justamente, superar essas insuficiências. Para tanto, vou tomar a alimentação menos como uma atividade que visa à produção de um corpo físico indeterminado, e mais como um dispositivo de produção de corpos aparentados. Foi justamente esse passo que me escapou na formulação do livro, embora vários autores já tivessem chamado a atenção para a importância da comensalidade como dispositivo identificatório. Este fenômeno tem sido elaborado pelos etnólogos amazonistas desde os estudos jê do projeto Harvard-Brasil Central e, no início dos anos 90, foi refinado pelos trabalhos de Gow (1991) e Vilaça (1992). Ora, se a idéia de fabricação do parentesco converge, na Amazônia, para o universo da cozinha e da partilha alimentar, nossa questão passa a ser o encadeamento de dois processos de transformação: um que resulta do comer alguém (o canibalismo), outro que decorre de se comer como e com alguém (a comensalidade) ${ }^{2}$.

A fim de examinar esse problema, vou começar por uma exposição geral sobre a relação entre caça e guerra, comparando a literatura sobre o Subártico Americano àquela sobre a Amazônia. Essa exposição fornecerá o contexto da discussão posterior, que trata do consumo de animais e das noções indígenas de doença, resguardo e transformação, na qual insiro a caça em um conjunto mais amplo de práticas e concepções acerca da relação entre humanos e animais. Elaborarei progressivamente o modo pelo qual canibalismo e comensalidade podem ser, simultaneamente, distinguidos e articulados, trilhando um caminho aberto pelo perspectivismo (Lima 1996; Viveiros de Castro 1996), para fazer o conceito de predação familiarizante reencontrar o de aparentamento. Essa elaboração se dará ao lado do desenvolvimento de um argumento sobre a partibilidade da pessoa nas cosmologias amazônicas, inspirado em Strathern (1988), com o qual procuro complexificar a relação entre corpo e alma.

\section{A dádiva animal}

Na esteira do trabalho pioneiro de Descola (1986), vários autores contemporâneos têm focalizado as relações entre humanos e não-humanos no pensamento e prática indígenas. A proposição de base que norteia essa 
reflexão é a de que, nas ontologias ameríndias, a intencionalidade e a consciência reflexiva não são atributos exclusivos da humanidade, mas, potencialmente, de todos os seres do cosmos. Em outras palavras, animais, vegetais, deuses e monstros podem também ser "pessoas" e ocupar a posição de sujeito na relação com os seres humanos. Dessa indistinção ontológica decorre uma série de problemas teórico-etnográficos, sendo que, aqui, nos interessa aquele que diz respeito ao estatuto da caça. Se predar animais equivale a matar pessoas, a caça resvala imediatamente na guerra; se ambos os fenômenos inscrevem-se no campo das relações sociais entre sujeitos dotados de intenção, o consumo alimentar resvala imediatamente no canibalismo. Pode-se, pois, perguntar, parafraseando Clastres, se o horizonte da caça não é o canibalismo generalizado, se a caça não é de fato uma guerra aos animais? ? $^{3}$

Essas questões foram postas, nestes ou em outros termos, pela literatura recente sobre sistemas ditos animistas, um conceito renascido das cinzas tylorianas na esteira da revisão das noções de natureza e cultura. Alguns desses estudos estabeleceram uma ruptura forte entre caça e guerra. Autores como Bird-David e Ingold, por exemplo, caracterizaram as relações entre humanos e não-humanos nas sociedades caçadorascoletoras como sendo essencialmente não-violentas, pois fundadas em uma "economia cósmica da partilha" (Bird-David 1990), em que o valor cardinal é a "confiança" (trust), definida como uma combinação peculiar de dependência e autonomia, envolvendo relações positivas e não coercitivas (Ingold 2000). Nesse paradigma, a caça aparece como uma partilha entre humanos e animais e, enquanto tal, opõe-se à relação guerreira entre humanos.

O exemplo clássico dessa concepção seria o dos caçadores da floresta boreal americana, falantes de línguas algonquinas e atapascanas. $\mathrm{Na}$ literatura, esse caso ocupa uma posição privilegiada por apresentar a forma mais acabada de conversão da predação cinegética em relação moralmente positiva. Para os caçadores boreais, os animais só são mortos porque se dispõem a morrer, sendo sua motivação descrita ora no idioma do amor-amizade e da compaixão, ora naquele do interesse e da reciprocidade: os animais cedem seu corpo porque gostam do caçador (ou dele se apiedam), e também o fazem porque os humanos lhes oferecem contraprestações durante refeições cerimoniais ${ }^{4}$. A caça é descrita, portanto, como uma relação positiva para ambas as partes, garantindo a reprodução da vida humana sem implicar a destruição do potencial de vida animal. Daí decorre uma forte ênfase ideológica na regeneração da caça e em uma etiqueta rigorosa que determina os modos de matar, consumir e falar 
sobre os animais. É preciso observar uma ética cuidadosa no tratamento das presas: morte rápida e limpa, corte e preparação apropriados, oferendas, deposição adequada dos ossos, consumo completo da carne. É preciso respeitar os animais sob pena de dificultar o processo de sua regeneração, de perder a comunicação onírica com eles, levando-os assim a desaparecer do território de caça.

Se esse modelo da caça responde ao problema moral da predação, ele não resolve, porém, o problema ontológico do canibalismo. Brightman, em seu livro sobre os Rock Cree, enfrenta a questão ao constatar a instabilidade das categorias ontológicas de animais e humanos: se eles partilham uma condição comum de pessoa, como diferenciar o caçador de um feiticeiro ou de um witiko, um canibal, que come humanos porque os vê como animais? Para o autor, a visão benévola da caça, hegemônica no Subártico, ofereceria um compromisso apaziguador para esse paradoxo insolúvel, pois negaria seu caráter de guerra e canibalismo (Brightman 1993:203)5. A redefinição da presa como doador, porém, dependeria da distinção entre um corpo zoomorfo e uma alma antropomórfica:

\footnotetext{
“A carne e a pele dos animais são representadas como distintas e repetidamente destacáveis da essência e identidade humanóides: o corpo é comparado a uma roupa que o animal descarta [...]. Não há canibalismo porque só há similitude do humano e do animal em relação à alma" (Brightman 1993:205206).
}

Temos aqui uma versão forte da idéia de regeneração, que supõe a descartabilidade de uma parte da pessoa animal: os animais só morrem aos olhos dos caçadores, pois o que eles cedem aos humanos - seus corpos - é como uma roupa da qual se desfazem no momento em que são alvejados ${ }^{6}$. Tanto a noção de regeneração como a de roupa apontam para a separação entre aquilo de que os humanos se apropriam e o potencial de vida que os animais conservam a despeito da caça. O problema ontológico do canibalismo resolver-se-ia, assim, por meio de uma separabilidade entre corpo e alma (a carne-comida distinguindo-se do animal-sujeito), enquanto o problema moral se resolveria pela ênfase na partilha e na compaixão entre humanos e animais. Eis, enfim, a resposta dos caçadores boreais (ou da literatura sobre eles) à questão de Clastres: a caça não é guerra, nem a alimentação carnívora é uma forma de canibalismo.

A seguir, procurarei mostrar que a resposta preponderante na Amazônia é diversa desta, e que ela só pode ser compreendida se inscrevermos a caça no campo mais amplo das relações de predação transespecífi- 
ca, as quais, como veremos, se vinculam ao desejo cósmico de produzir o parentesco.

\section{Os animais em guerra}

Quando passamos da floresta boreal para a tropical, parece haver uma inversão de dominância entre os esquemas de relação humano-animal: se no Subártico, a dádiva e a reciprocidade imperam, na Amazônia, o esquema mais produtivo parece ser o da predação. É difícil dizer se esse contraste é apenas empírico ou se resulta também das diferenças de abordagens dos pesquisadores de cada região; tampouco sabemos se corresponde a uma distinção de longa duração ou se é um fenômeno historicamente recente. Para os fins deste artigo, o contraste, seja ele literal ou literário, permite apontar não apenas maneiras diferentes de conceitualizar a atividade cinegética - algo que, como mostrou Descola (1992), pode aplicar-se internamente à Amazônia - , mas sobretudo chamar a atenção para um aspecto pouco explorado no caso boreal e que me parece central na floresta tropical: o fato de que a predação é um vetor de socialidade transespecífica. Interessa-me menos sugerir que os modelos da dádiva e da reciprocidade têm relativamente uma produtividade menor na Amazônia, do que inserir a caça em um conjunto de relações predatórias entre diferentes tipos de gente. Meu argumento supõe que humanos e animais estão imersos em um sistema sociocósmico no qual o objeto em disputa é a direção da predação e a produção do parentesco.

Essa ênfase amazônica na predação transespecífica modula certos temas extremamente elaborados no Subártico americano. Tomemos a noção de que os animais não morrem definitivamente, mas se regeneram. É possível citar vários exemplos dessa concepção na Amazônia (Århem 1996:196; Karadimas 1997:406; Vilaça 1992:61). No entanto, se no Subártico há uma verdadeira obsessão pela deposição correta dos ossos das presas para permitir sua regeneração, na Amazônia há um relativo descuido, quando não uma total displicência, com relação aos restos dos animais. Em um contexto no qual os mestres da caça são tidos como xamãs e os xamãs são reputados capazes de revivificar um morto a partir dos ossos, esse menor cuidado sugere que a regeneração das vítimas não é a preocupação central do caçador amazônico. Minha hipótese é que esse fato está relacionado ao foco na transformabilidade dos entes. Explico-me. O modelo benévolo da caça tende a postular uma série de ciclos fechados próprios a cada espécie - o caribu renasce como caribu, o urso como ur- 
so, e assim por diante. No caso amazônico, ao contrário, esses ciclos tendem a confundir-se: o humano passa a não-humano e vice-versa. Essa passagem pode ser tanto um evento particular diferenciado (a morte de $\mathrm{X}$ causada pela espécie agressora $\mathrm{W}$; a concepção de $\mathrm{Y}$ produto da predação Z), como uma condição geral (os humanos quando mortos se tornam animais; uma vida concebida é apropriação de princípios vitais de outras espécies). É certo que, em alguns casos, como o do Noroeste Amazônico, onde há transmissão vertical de identidade, o ideal é manter os ciclos fechados, inclusive no plano dos clãs exogâmicos: almas humanas devem voltar às "Casas" dos ancestrais e renascer como o mesmo tipo de gente. O problema é que há sempre o risco de, por meio da doença, tornar-se um animal ou, por meio da guerra, tornar-se um inimigo.

Nesse mesmo contexto rio-negrino, onde além do ideal de recursividade vertical há uma forte valorização da reciprocidade, a predação de animais encadeia-se à de humanos. Os Desana dizem que os mestres dos animais só liberam seus protegidos para serem caçados se forem pagos em almas humanas. Essa troca interespecífica só é possível, porém, graças à negação da reciprocidade alhures, pois ela supõe a predação nãorecíproca entre humanos: os xamãs não trocam seus parentes pelos animais familiares do mestre, mas sim seus inimigos (Reichel-Dolmatoff 1973:160). A negociação implica a predação contra outros humanos na forma de feitiçaria, ato que pode ser concebido à maneira de uma caçada, como aponta Chaumeil para os Yágua (1983:233), ou à maneira de uma guerra invisível, como indica Albert para os Yanomami (1985).

O encadeamento dos ciclos predatórios costuma, com maior freqüência, opor diretamente humanos e animais, e esse fato inflete outro tema crucial para os caçadores do Subártico: o respeito à presa animal. Regras impondo formas próprias de matar, cuidados no trato da caça, limitação da predação foram também descritas pela literatura amazônica. No entanto, mesmo quando essas prescrições e proibições são ditas na linguagem do respeito, o desrespeito dá antes lugar à guerra de vingança do que ao desaparecimento da caça de um certo território (ver Gray 1997:50). Enquanto no Subártico se afirma ser imperativo encontrar animais feridos, pois deixar a presa morrer sofrendo inutilmente perturba a harmonia que deve imperar nas relações entre humanos e animais (Brightman 1993:110), na Amazônia, esse mesmo cuidado é justificado pelo temor do caçador de ser alvo de uma contrapredação. Assim, entre os Tikuna, a fuga de um animal ferido leva a uma busca obsessiva, pois se a presa retornar à sua casa e contar o que lhe sucedeu, o caçador encontrar-seá ameaçado pela vingança do "pai" daquela espécie (Goulard 1998:414). 
O conjunto de práticas e crenças relativas ao tratamento da presa, que costumamos designar "ética da caça", remete sobretudo a esse perigo de inversão das posições respectivas de predador e de presa. Por isso, na Amazônia, a conseqüência do não-cumprimento dessas práticas é expressa em termos de vendeta: o que se quer evitar, sobretudo, é ter que pagar a morte do animal com a própria vida ou com aquela de um parente. Em certos casos, quando já se instaurou o ciclo da vingança, a agressão pode mesmo sobrepor-se às prescrições para o tratamento adequado da presa. O caçador miraña, movido pelo desejo de retaliação, pode impedir a regeneração de sua vítima: em vez de deixar o sangue verter sobre o chão da floresta e abandonar a cabeça e as tripas do animal, ele o retalha na água, uma prática corrente quando se trata de "uma anta que se suspeita ser particularmente responsável por várias doenças." (Karadimas 1997:407). Aqui, a caça resvala intencionalmente na guerra de vingança, mas a imbricação dos dois fenômenos é muito mais generalizada, e ganha enorme produtividade na nosologia indígena.

Guerra e doença podem prestar-se a significar diferentes perspectivas sobre um mesmo evento: o que é doença para os humanos pode ser guerra para os animais. Aos olhos humanos, temos um ato de feitiçaria que conduz a estados mórbidos, mas da perspectiva dos animais, trata-se antes de uma guerra de captura. Assim, os Miraña afirmam que a humanidade está exposta à agressão dos espíritos de animais, pois estes podem perseguir "os descendentes dos humanos para raptá-los e levá-los para baixo da terra onde se encontram suas malocas, transformando-os em sua própria descendência [...]" (Karadimas 1997:404). Entre os Wari', muitas doenças são tidas como resultado do ataque de um animal que retém consigo a "alma" da pessoa. Se seu corpo definha diante dos parentes, aos olhos do xamã que tenta curá-lo, ele está se transformando e adquirindo as características do animal agressor (Vilaça 1992; 2002), i.e., está ganhando um novo corpo e novos hábitos, capacidades e afetos, da mesma forma que uma pessoa capturada na guerra deve ser familiarizada por seus raptores. Lagrou, por sua vez, sugere que os Kaxinawá concebem a doença como "um processo perigoso e incontrolável de alteração" (1998:45), uma metamorfose na qual o humano estaria sendo predado e familiarizado pela espécie animal agressora. A doença por "rapto da alma" comporta, em suma, duas ordens de realidade: para os parentes humanos do paciente - que o vêem definhar, perder a força e esvair-se trata-se de uma morte; já para a entidade que roubou a alma, trata-se da transformação de um outro em parente. A doença seria, enfim, a predação familiarizante dos animais. 
A ética da caça visaria evitar que a atividade cinegética aparecesse simultaneamente para animais e para humanos como uma guerra de captura. Esse parece ser, como mostra Lima (1996), o significado da moderação verbal que caracteriza a caçada aos porcos entre os Juruna. Um caçador que abusa da linguagem condena-se à morte, ou ainda, condena-se a se tornar um animal. Seu corpo morto será encontrado pelos companheiros, mas sua pessoa será incorporada à vara de porcos, adquirindo pouco a pouco um corpo porcino até virar completamente um deles. Essa forma de apropriação da alma ou da pessoa do inimigo é característica da guerra entre humanos: o homicídio detona um processo de familiarização da vítima que desemboca, por intermédio de resguardos e rituais, na produção de novas pessoas na comunidade do matador. No caso juruna, portanto, os porcos fazem de fato a guerra ao serem caçados, capturando humanos e transformando-os em porcos e parentes. Mas, para que isso ocorra, é preciso que o caçador, por meio da imoderação verbal, partilhe da perspectiva de suas presas.

Na Amazônia, enfim, ao contrário do Subártico, a caça pode ser, da perspectiva dos animais, uma guerra. Diríamos, pois, a contrapelo de Clastres, que ela é sim uma guerra aos bisões, mas somente deve sê-lo do ponto de vista dos bisões. Esta restrição é fundamental. Vejamos por quê.

\section{Da caça à comida}

Humanos e animais estão imersos em uma rede sociocósmica onde se disputam potencialidades de existência e capacidades reprodutivas (em sentido amplo). Nessa rede, a oposição fundamental não é entre ser ou não ser humano, mas sim entre ser ou não ser parente (e entre ter ou não ter parente). A noção de predação familiarizante com que procurei caracterizar a atividade guerreira e o xamanismo na Amazônia aplica-se ao conjunto dessas relações de captura, que articulam de modo dinâmico o exterior ao interior, o outro ao mesmo. Nesse universo em que nada se cria e tudo se apropria, diferentes grupos, humanos ou não-humanos, vivos ou mortos, relacionados como meta-afins (Taylor 2000:312), procuram capturar pessoas para transformá-las em parentes. Xamãs capturam espíritos de animais e guerreiros capturam espíritos de inimigos, fertilizando as mulheres, dando nomes às crianças, produzindo cantos para os rituais, favorecendo a caça. Mas os não-humanos também capturam humanos, seduzindo-os e/ou predando-os, para transformá-los igualmente em mem- 
bros de sua comunidade. A predação está, assim, intimamente associada ao desejo cósmico de produzir o parentesco. Todo movimento de apropriação detona um outro processo de fabricação-familiarização, que consiste em dar corpo ao princípio exterior de existência e fazê-lo interior. Isso significa dotá-lo das disposições características da "espécie" do captor e, assim, aparentá-lo. Na feliz expressão de Vilaça (2002), a familiarização é um meio de fazer "parentes out of others".

E aqui se recoloca o problema da caça: para que os humanos constituam afetos e disposições humanas e produzam o parentesco entre si é preciso caçar: "Porcos mortos são comidos", escreve Gow, "para satisfazer o intenso desejo humano de comer caça e, por meio da satisfação desse desejo, criar laços de parentesco." (2001:70). A partilha da carne e a comensalidade não apenas marcam as relações entre parentes, como as produzem. Comer como alguém e com alguém é um forte vetor de identidade, assim como se abster por ou com alguém ${ }^{7}$. A partilha do alimento e do código culinário fabrica, portanto, pessoas da mesma espécie. O caçador juruna, após ser capturado, precisa ser feito porco: "alimentando-se de cocos e minhocas, participando das danças e bebendo o cauim barrento, o caçador infeliz, com o passar do tempo, vai assumindo o aspecto do animal" (Lima 1996:25). Segundo a mesma lógica, o xamã wari' encontra no corpo de seu paciente comida da espécie animal responsável pela doença, testemunhando que animal e humano se estão tornando comensais e, portanto, aparentando-se, no duplo sentido de tornar-se parente e parecido (Vilaça 2002).

A comensalidade é um vetor de identificação que não se aplica apenas às relações sociologicamente visíveis entre parentes humanos. Ela é um dispositivo geral que serve para pensar a passagem de uma condição de parentesco à outra e, portanto, aquilo que chamei de familiarização ${ }^{8}$. Em um mito parakanã, que é a versão local do desaninhador de araras, essa idéia se manifesta na forma de um alerta. Após descer da árvore em que fora abandonado, o protagonista procura seus parentes. Ele chega à aldeia das antas, onde é bem acolhido, mas como sente saudades dos seus resolve partir. As antas indicam-lhe o caminho, mas alertam-no para que não coma o mingau de minhoca na aldeia dos tatus. A conclusão é clara: comer com e como os tatus produziria o esquecimento do seu parentesco com os humanos. Não comer como e com é recusar o aparentamento e tal recusa equivale a se colocar na posição de inimigo. Assim, ocorreu com um menino que os Parakanã raptaram junto com a mãe em uma excursão guerreira na década de 40. Cativos, eles tentaram escapar, mas os Parakanã foram em busca deles e os interceptaram. Antes de matá- 
los, um homem repreendeu o menino, em tom de lamento: "eu disse para você comer a anta que eu caçara, foi o que eu disse em vão para você".

Esse mesmo dispositivo de identificação está presente nas escatologias amazônicas, nas quais, amiúde, a morte só se torna definitiva quando a pessoa aceita a comida ou a bebida que lhe é oferecida pelos $\operatorname{mortos}^{9}$. Esse ato alimentar é o desfecho de um processo detonado pela predação ontológica que produziu a doença e deu início à transformação do paciente em uma outra espécie de pessoa, transformação esta que, muitas vezes, é concebida como uma passagem do humano ao animal.

Há, enfim, uma concepção difundida de que comer como e com alguém inicia ou completa um processo de transformação que conduz à identificação com este alguém. O problema complexifica-se, no entanto, pelo fato de que é igualmente difundida a noção de que comer alguém desencadeia outro processo de transformação, que conduz à identificação entre o predador e a presa - uma identificação que, como sabemos, é ambivalente, pois não se dá em uma única direção ${ }^{10}$. A questão geral que se nos apresenta, portanto, é: qual a relação entre esses dois processos de transformação, um produzido pelo comer como e com alguém, o outro desencadeado pelo comer alguém? No contexto específico deste ensaio, trata-se de saber como é possível produzir o parentesco entre humanos e comer animais que são pessoas. Ou, mais precisamente, como os humanos podem identificar-se entre si ao comerem juntos comida própria aos humanos sem, no entanto, se identificarem com aquilo que comem?

A resposta é simples: é preciso separar cuidadosamente as duas operações. Comer e dar de comer para produzir o parentesco deve ser distinto do comer para identificar-se ao outro ingerido. Mas isso implica trabalho, pois a caça tem que ser produzida como comida, já que ela não é "naturalmente" um objeto. Em outras palavras, é preciso reduzir um animalsujeito à condição de objeto-inerte, é preciso "desagentivá-lo". A língua parakanã possui uma maneira elegante de marcar essa redução: uma caça morta antes do tratamento culinário é dita temiara, um termo formado pela agregação de um marcador de paciente a um marcador de agente. Após ser cozida, ela será dita temi'oa, onde o marcador de agente é substituído pelo verbo "comer" ('o) e por um nominalizador não-agentivo. Transformar uma caça em comida é desprovê-la da capacidade de agir e de entrar em relação com um outro, capacidade que é própria aos seres em sua condição de pessoa. A relação sujeito-ativo e objeto-inerte não resulta imediatamente do ato predatório, da passagem de uma tensão predatória (Taylor 2000) a um estado de predação, requerendo, portanto, um trabalho suplementar de redução da caça à comida. 
A capacidade que, na falta de melhor termo, podemos chamar "agentiva" é distribuída desigualmente no cosmos — não apenas porque nem tudo a tem, mas também porque há uma hierarquia entre os seres que a têm. Tanto na Amazônia, como no Subártico, a cadeia alimentar é um indexador cardinal de agentividade. Grandes predadores como o jaguar e a anaconda ocupam o topo dessa hierarquia, enquanto peixes e vegetais ocupam o solo. Animais estão, em geral, acima das plantas, mas podem estar abaixo daquelas de efeito psicotrópico. Carnívoros tendem a estar acima de herbívoros. Há, no entanto, variações significativas em função de outras características que não dizem respeito à cadeia alimentar, mas sim à cor, ao tamanho, ao comportamento, à associação ecológica e assim por diante ${ }^{11}$.

Os cuidados no comer variam em função da atribuição relativa de agentividade a cada uma das espécies. Os Kaxinawá, por exemplo, distinguem entre animais com yuxin, sem yuxin e que são puro yuxin (esta categoria, traduzida amiúde como "alma", conota uma capacidade de ação transformativa). Os animais sem yuxin são inofensivos, pois são apenas animais e não podem agir como pessoas. Já os animais com yuxin, dentre os quais se conta a maioria dos animais comestíveis, são perigosos, pois podem retaliar os atos de predação cinegética, causando doença nos humanos. Finalmente, os animais que são puro yuxin são perigosos e incomestíveis (Lagrou 1998:41-43). Os Miraña, por sua vez, distinguem animais que são vegetais daqueles que são pessoas. Os primeiros são produtos da roça dos deuses e não são vetores de doenças, enquanto os segundos oferecem risco aos humanos. O problema é determinar quais animais são uma coisa ou outra. Pequenos pássaros e roedores são, por definição, vegetais, enquanto grandes predadores são sempre pessoas. Entre essas duas categorias, no entanto, se encontram as presas mais comuns dos caçadores, as quais podem tanto ser gente como vegetais (Karadimas 1997:405, 577-583).

Como toda ou quase toda caça comestível pode agir como sujeito, é preciso produzi-la enquanto comida antes do consumo. Daí a importância da xamanização da caça na Amazônia, operação que permite neutralizar ou reduzir a capacidade agentiva-transformativa do animal. Assim, entre os Piaroa, o xamã transubstancia a carne em planta a fim de tornála comestível (Overing Kaplan 1975:39), enquanto entre os Barasana ele reduz mamíferos à condição de peixes (Hugh-Jones 1996). Por vezes, essa atividade se dirige apenas a certas presas: os Ticuna só a praticavam no caso da anta, único animal reputado capaz de vingar-se diretamente dos humanos (Goulard 1998:430), enquanto os Wari', que hoje focalizam ape- 
nas os queixadas, antes a praticavam com quase todas as espécies predadas (Vilaça 1992:61). Xamanizar o animal morto, porém, não basta. É preciso neutralizar sua condição subjetiva por meio do cozimento. O fogo de cozinha é um operador central na redução de animais-sujeitos em animaisobjetos. A técnica empregada não é, porém, indiferente: o cozido oferece menos risco que o assado, pois, como já indicara Lévi-Strauss (1965), este último se aproxima do cru. Os Arakmbut do Peru, por exemplo, evitam o assado por temerem um cozimento incompleto (Gray 1996:154), enquanto o caçador de jaguar miraña "assa ligeiramente" sua presa para comê-la à maneira crua (ver abaixo) ${ }^{12}$. Tampouco são iguais as partes do corpo: a cabeça costuma ser cercada de interditos especiais, mas é sobretudo o sangue (e seu odor) que funciona como indexador sensível de agência transformativa. Por isso, qualquer traço de sangue pode oferecer risco, e a comida na Amazônia costuma ser hipercozida. Mesmo em um contexto como o do Alto Xingu, onde a alimentação animal se resume basicamente ao pescado, pode-se ouvir a acusação contra uma aldeia vizinha de que sua gente come "peixe mal cozido" (Gregor 1990).

A oposição entre comer cru e comer cozido é fundamental, pois marca duas formas muito diversas de consumo: devorar cru define, de saída, tanto a intenção quanto o resultado do ato de consumo, enquanto comer (bem) cozido define a intenção, mas guarda sempre uma ambigüidade, pois não se sabe jamais se o alimento foi completamente objetificado. A mesma diferença de cozinha é central no Subártico Americano ${ }^{13}$. Brightman afirma que "o processo de cozimento bloqueia a aquisição, por parte daquele que come, de propriedades imateriais [...] contidas na comida crua" (1993:143), enquanto a omofagia implica justamente a ingestão dessas propriedades. Haveria, pois, duas modalidades de consumo: uma, cozida, cujo objetivo é alimentar em sentido estrito; outra, crua, cujo fim seria apropriar-se de capacidades anímicas da vítima.

Deixem-me refrasear essa oposição para que não se a confunda com um dualismo cartesiano, hoje rejeitado quase unanimemente na caracterização das ontologias ameríndias ${ }^{14}$. Esse dualismo não nos permite explicar, por exemplo, por que beber sangue ou comer carne crua - partes substantivas do corpo - implica a apropriação de capacidades subjetivas da vítima. Que não haja uma fratura absoluta entre corpo-material e alma-imaterial não significa, porém, a inexistência de outra distinção que, provisoriamente, marcaremos como sendo aquela entre um consumo do outro enquanto pessoa (ou em sua condição de pessoa) e seu consumo na condição de comida (ver Fausto 2001:538). Essa distinção pode ser aproximada daquela entre sujeito e objeto, desde que entendamos que o valor 
não-marcado dos animais é o de sujeito. Isso não quer dizer que todos os indivíduos de uma espécie, ou que todas as espécies, realizem esse valor da mesma maneira e em todos os momentos. Trata-se, porém, de uma premissa das ontologias ameríndias. Ora, se os animais ou certos animais são pessoas, devorá-los nessa condição é apropriar-se de suas qualidades enquanto sujeito: é isto que se faz ao comê-lo cru. Ao contrário, cozinhá-lo é desprovê-lo dessa condição, é transformá-lo em objeto, tornando-o próprio ao consumo cotidiano.

Redefinamos, pois, a noção de canibalismo: é canibal toda devoração (literal ou simbólica) do outro em sua condição (crua) de pessoa, condição que é o valor default. Já o consumo não-canibal supõe um processo de dessubjetivação da presa, de redução a objeto, no qual o fogo culinário tem um papel central. Na alimentação cotidiana, é preciso que o animal enquanto sujeito esteja ausente para que a identificação possa se produzir entre os humanos. É necessário bloquear a relação, sempre possível, entre o humano e o animal, a fim de que, por meio da carne deste último, os comensais possam se produzir enquanto humanos e parentes. A alimentação cotidiana, porém, nem sempre é desejável ou segura. Por vezes, é preciso ficar aquém dela, por vezes é preciso ir além. Na seção seguinte, trato do primeiro caso, na subseqüente, do segundo.

\section{Resguardo e transformação}

Há momentos em que o comer torna-se foco de restrições estritas, que se diferenciam dos interditos e precauções cotidianos. Trata-se de períodos em que processos de transformação já estão em curso e são marcados pelo resguardo. O nascimento é um bom exemplo disso. O parto é a exteriorização de um processo interno de transformação, que costuma remontar à captura de um princípio vital externo ${ }^{15}$. A fabricação-transformação da criança não se interrompe, contudo, com o nascimento; ao contrário, o período pós-natal é crucial para a definição da "espécie" do bebê: pai, mãe e sua parentela concentram esforços para fabricá-lo como pessoa humana e aparentada (ver Gow 1997). Como aponta Vilaça em seu ensaio sobre a couvade, o corpo do recém-nascido, "no processo de sua criação, corre o risco de ser feito igual ao corpo de outros tipos de pessoas (ou simplesmente de animais)." (2002:359). Eis por que as mulheres parakanã passam horas e horas a massagear o bebê. Segundo dizem, são essas operações que tornam os corpos humanos diferentes dos corpos dos animais, os quais, com exceção dos bichos de estimação, não são jamais modelados. 
As ações sobre o corpo servem, assim, para fixar uma forma e um destino: "Aplicações ocasionais de jenipapo", escreve McCallum sobre os Kaxinawá, "parecem 'fixar' a forma fabricada pelo trabalho intenso dos parentes tanto durante quanto após a gravidez; ao mesmo tempo, o jenipapo torna o bebê invisível aos espíritos." (2001:21).

O tornar-se invisível aos espíritos remete-nos novamente ao problema da captura. É comum, na Amazônia, conceber-se que o princípio vital do bebê não está seguramente ligado ao corpo e que, por isso, pode ser capturado. O bebê ainda não foi inteiramente fabricado como membro de sua comunidade, e pode ser feito parente de outra gente, animais ou inimigos. No momento da couvade, deve-se, portanto, fechar as portas à interação com o exterior, algo que se evidencia, entre outras coisas, pela interdição ao pai de participar da caça, da guerra, dos rituais e das atividades xamânicas. O risco aqui não diz respeito apenas à criança, pois o pai também está em transformação e pode tornar-se outro. Segundo Schaden, os Guarani Nandeva denominam odjepotá essa ameaça que paira sobre o genitor ${ }^{16}$ :

“O odjepotá é o destino de todo homem que, desrespeitando o resguardo, sai para caçar: 'o primeiro animal que encontra afigura-se-lhe como gente, atraio e torna-o odjepotá'; no dizer de um informante Ñandéva do Bananal, 'o bicho se mistura com a gente e a gente fica vivendo com o bicho toda a vida'" (Schaden 1954:102).

Esse mesmo perigo, o de transformar-se em animal, afeta a menina guarani em resguardo da menarca e o homem parakanã em resguardo pós-homicídio. No primeiro caso, diz-se que ela pode ser atraída por um "bicho-homem" que a leva consigo. Crescem-lhe então pêlos sobre o corpo e ela se torna uma ameaça para os humanos. Já o matador parakanã, assim como o pai em couvade, não pode sair para caçar. O destino daquele que desrespeita esse interdito é explicitado nos mitos. Conta um deles que um homem em resguardo teve que sair para caçar, pois seu filho tinha fome e ninguém na aldeia o alimentava. Ele encontrou uma vara de porcos e começou a matá-los. Como estava só, acabou desarmado e refugiou-se nos galhos de uma árvore. Foi então derrubado e os porcos o levaram embora para sempre.

O mito inicia-se pela recusa do parentesco (os aldeãos não reconhecem a criança como parente e lhe negam comida) e termina com a captura do matador pelos porcos. Estabelece-se, pois, um vínculo entre a negação da primeira relação (entre humanos) e a produção de uma segunda 
relação (entre o humano e os animais). Essa mesma idéia aparece entre os Kayabi: uma pessoa maltratada pelos parentes está exposta a ter sua alma raptada pelos espíritos, que fazem dela um familiar (Oakdale 1998). Os Kaxinawá, por sua vez, afirmam que "pessoas tristes ou enraivecidas, insatisfeitas com sua relação com parentes próximos ou esposos, [...] tendem a dar ouvido aos chamados de yuxin à noite, e então desaparecem ao sonambular pela floresta." (Lagrou 1998:45). Esse processo de desafeição por parte dos parentes equivale, assim, a um processo patológico. Em um artigo ainda inédito, Taylor (s/d) mostra como, entre os Jívaro, a erosão da teia de relações que constitui a pessoa induz a "um tipo de anemia sociológica que se traduz em sintomas de doença e reclamos de se estar órfão." A doença vivida como orfandade aponta para esse duplo movimento que envolve o rompimento de relações de parentesco e sua recriação alhures. A doença, essa metamorfose indesejada, tem como agente um sujeito-outro que deseja produzir o seu próprio parentesco. A transformação vista, do lado de cá, como doença-desafeição é, do lado de lá, uma predação-afeição. A diferença entre doença e guerra, portanto, não é da ordem do processo, mas do ponto de vista.

Em suma, se há uma competição potencial entre diferentes "espécies", humanas e animais, por pessoas que se quer fabricar como parentes, se a recusa do parentesco abre caminho para a produção de uma nova relação, que passa necessariamente por uma metamorfose, por que as condições pós-natal, pós-menarca e pós-homicídio são particularmente sensíveis, por que devem ser cercadas de interditos? O perigo parece derivar do fato de que já há uma metamorfose em curso, que se evidencia pela presença e o odor do sangue, substância transformativa por excelência. Mas que metamorfose é essa, qual o risco envolvido?

No caso do homicídio, o que está em jogo é a direção da familiarização: o matador, em vez de controlar a vítima, corre o risco de ser controlado por ela, assumindo em definitivo sua perspectiva. Por isso, seus parentes colocam-no em reclusão: por um lado, forçam-no a focalizar a relação com sua vítima, interditando alimentos e atividades que poderiam conduzi-lo a interagir com outros sujeitos e levá-lo a um desvio de rota; por outro, lembram-lhe com insistência que ele é um parente e não um inimigo $^{17}$. Pode-se dizer, assim, que enquanto o matador familiariza a vítima, os parentes refamiliarizam o matador e a sua vítima. O mesmo pode ser dito da couvade. Como vimos, o nascimento de uma criança requer a apropriação de um potencial de existência que é exterior ao corpo de parentes e que, portanto, precisa ser aparentada. Também aqui é necessário focalizar certas relações e bloquear outras. Assim, enquanto pai e mãe fami- 
liarizam a criança, a comunidade de parentes familiariza os pais e a criança. No caso da menarca, contudo, não há apropriação de um novo sujeito (não há vítima, nem bebê); há, sim, a produção de uma condição que permitirá à mulher ser receptáculo ativo para uma transformação não-visível (a gestação), que serve de modelo-analógico para outra transformação, a do matador, também só objetivável em suas manifestações externas (os cantos e nomes providos pela vítima e transferidos à comunidade).

Em suma, os resguardos procuram controlar processos de transformação, evitando que tomem direção errada. Não se trata de obviá-los, mas de evitar que esse potencial de movimento seja apropriado por outros sujeitos do cosmos. Por isso, nesses momentos, o universo relacional deve ser limitado. O número expressivo de restrições alimentares durante os resguardos sugere que comer é uma atividade particularmente delicada, pois pode converter-se em uma relação social entre sujeitos. Mesmo todo o processamento xamânico e culinário não é suficiente para transformar o consumo alimentar em uma relação segura entre um sujeito-ativo e um objeto-neutro; resta sempre um traço de atividade e subjetividade no animal, de tal modo que, em certas circunstâncias, é preciso de quase tudo se abster ${ }^{18}$.

\section{Da comida à pessoa}

A comida na Amazônia não deve ser sempre apenas comida. Se há momentos em que se multiplicam as proibições, há outros em que se trata de desencadear processos de transformação por meio do consumo de animais interditos. Estes animais são normalmente predadores e costumam ser consumidos crus ou assados. Para desenvolver a capacidade onírica dos jovens parakanã, os adultos davam-lhes para comer certas partes assadas da ariranha, equiparada na Amazônia a um jaguar aquático. Já os homens kaxinawá consumiam cru o coração e a língua da jibóia (as mulheres comiam os olhos), para adquirir suas capacidades (Lagrou 1998: 62). Entre os Yágua, um homem que matasse um jaguar deveria comer seu coração ainda pulsante para adquirir força e coragem (Chaumeil, inf. pessoal).

A essa ingestão real de animais interditos, especialmente predadores, soma-se uma série de outras práticas rituais que visam ao mesmo objetivo, mas que não implicam o consumo da carne. Assim, por exemplo, os Tupinambá substituíam o cativo humano por um jaguar para iniciar os jovens na praça. O felino era morto ritualmente, mas, ao contrário do inimi- 
go, não era comido. Os Parakanã dançam com um jaguar morto para transfazer-se no predador: vestido com sua pele e dotado de suas capacidades, o sonhador sai à noite para caçar. Já os Yanomami realizam um ritual antes de partirem para a guerra, cujo objetivo é incorporar imagens vitais de certos animais, notadamente do urubu, que devorarão a vítima durante o resguardo pós-homicídio (Albert 1985:363). Em todos esses exemplos, trata-se de produzir transformações em certas pessoas para que elas possam interagir com não-parentes e familiarizá-los. Visa-se, aqui, constituí-las como termos potenciais de uma relação futura de predação familiarizante.

A essas práticas alimentares nas quais os animais não são tomados como comida mas como fonte de capacidades, pode-se acrescentar ainda o consumo de narcóticos e de alucinógenos. Explorei em outro texto as conexões entre o tabaco e o jaguar na América do Sul (Fausto no prelo). Quanto aos alucinógenos, noto a recorrente associação da ayahuasca (Banisteriopsis caapi) aos grandes predadores. Segundo Harner (1973: 160), cobras (em especial, a anaconda) e jaguares são os animais mais citados nas descrições dos índios sobre os efeitos da bebida. Os Mawé estabelecem uma associação direta entre a droga e os felídeos: segundo um xamã "o mestre do /kapi/ é uma onça-pintada [...] quando o cultivamos com água tingida de sangue [i.e., aquela com que se lavou a caça], ele se torna muito selvagem" (apud Giraldo-Figueroa 1997:276). A associação entre hematofagia e psicotrópicos encontra-se ainda entre os Miraña: a coca é guardada em um saquinho designado "bolso do espírito devorador", espírito que é um comedor de carne crua e de sangue (Karadimas 1997:376, 576). No Noroeste Amazônico, a coca e a ayahuasca são concebidas como partes dos corpos dos ancestrais, que são, eles mesmos, predadores (Hugh-Jones, inf. pessoal) ${ }^{19}$.

Finalmente, e aqui retorno à ingestão efetiva de carne de animais interditos, temos um exemplo que explicita a correlação entre essa modalidade de consumo e a predação guerreira. Os Miraña praticavam no passado o exocanibalismo e confeccionavam colares com os dentes das vítimas. A retirada dos dentes era o último estágio de um processo de familiarização-consangüinização do inimigo, que tinha início com o próprio ato homicida. Ao portar o colar, o matador mobilizava o potencial predador de sua vítima, seu gwásà, e podia utilizá-lo contra os ex-consangüíneos do morto. A mesma prática visa, hoje como no passado, ao jaguar. Após matá-lo, o caçador extrai os caninos e entrega-os a um xamã. Corta também a cauda (ou retira o fígado), que comerá "ligeiramente assada" para não temer o encontro com o espírito do jaguar. O xamã convoca-o então, e tomado por ele engaja-se em um diálogo com o matador, cujo objeti- 
vo é transformar o jaguar em um auxiliar xamânico. Os dentes caninos serão a nova morada do gwásà do felino e sempre que precisar da ajuda de seu auxiliar, o xamã-caçador tomará o colar e invocará o espírito do jaguar (Karadimas 1997:395).

Essa prática miraña fornece um bom exemplo do que denominei predação familiarizante: a conversão de relações de predação em familiarização, modelizada como uma passagem da afinidade à consangüinidade. A predação familiarizante caracteriza tanto a operação de domesticação da vítima humana na guerra, como a da vítima animal no xamanismo. Neste, porém, a articulação entre caça e familiarização não é imediata, a não ser quando o animal é devorado (literal ou simbolicamente) em sua condição de pessoa, como nos casos descritos acima. Mas nestes casos a presa animal é equivalente a uma vítima humana, e a caça não se distingue do homicídio guerreiro. No cotidiano, ao contrário, a caça deve ser distinguida da guerra, e mesmo o consumo de um animal não interdito precisa, em determinados momentos e circunstâncias, ser cercado de precauções rituais para transformá-lo em comida.

\section{Caçando porcos}

Eis por que, finalmente, a caça só pode ser guerra do ponto de vista dos animais. Se não há barreira ontológica entre humano e não-humano, os humanos devem trabalhar para distinguir o consumo do animal como comida de seu consumo enquanto pessoa. Confundir a caça com a guerra é, como diz Lima a propósito dos Juruna, afirmar o ponto de vista dos porcos: "uma luta [...] está em curso - luta entre a caça de um e a guerra de outro. O infortúnio do caçador é o resvalamento da caçada na guerra." (1996:37-38). O interdito verbal juruna implicaria, pois, antes que uma afirmação da perspectiva do caçador, a construção dessa perspectiva. Nesse sentido, ele já é parte do processo de dessubjetivação do futuro alimento, de transformação da pessoa em comida (sendo que o próprio ato de comer é um momento desse processo). O pressuposto - de que os porcos são humanos - continua lá, mas é negado pela posição de um interdito, que instaura uma assimetria entre a posição da presa e a do predador. É preciso afirmar a intenção de comer carne e não de fazer guerra. Essa diferença pode ser marcada por um afastamento mínimo, como ocorria entre os Kaxinawá que utilizavam a mesma borduna para dar cabo de porcos e de inimigos, mas jamais o mesmo lado da borduna (Kensinger 1975 apud Erikson 1986:205). 
Como afirma Erikson, se os predadores são por vezes inimigos, a caça "não deve, sobretudo, ser tratada como um inimigo" (1986:194). Para tanto, é preciso produzir diferenças. Assim, os Xaranawá matavam jaguares com lanças de guerra, mas os animais que lhes servem de alimento eram mortos com arco-e-flecha (Siskind 1973:174). A utilização da diferença entre técnicas cinegéticas para produzir uma distinção entre guerra e caça é recorrente na Amazônia, mas ela não recorta a fauna sempre da mesma maneira. Se a predação de jaguares é quase universalmente equiparada à morte de inimigos, a caça de outros grandes mamíferos terrestres também pode ser aproximada à guerra. A espécie-foco aqui costuma ser o queixada, que fornece um modelo da própria condição humana genérica: eles não são pura capacidade predatória, mas antes mortais a serem predados, que se defendem bravamente, vivem em grupo, comem mandioca e têm um chefe. Eles se aproximam dos humanos pelo gregarismo (conotando sua capacidade em produzir o parentesco), pela organização social da vara (conotando o reconhecimento de outras relações assimétricas que não a devoração) e pela sua condição ambivalente, a meio caminho entre a presa e o predador. O jaguar, ao contrário, é marcado pela solidão e por uma capacidade predatória quase ilimitada, que é desigualmente distribuída entre os humanos (pois é um suplemento característico de guerreiros, xamãs e caçadores) e aponta para a superação da própria condição humana (seja positivamente como imortalidade ou negativamente como anti-sociabilidade).

A pregnância dos queixadas como metáfora da condição humana faz de sua caçada, não apenas por razões técnicas, um evento saliente dentre as demais atividades cinegéticas. Não é por acaso que vários povos amazônicos aproximam a caça aos porcos da guerra, destacando-a da predação de outros animais. As populações que utilizam a zarabatana, por exemplo, costumam opor essa técnica, dirigida a espécies arborícolas, àquela que decorre do uso do arco ou da lança, utilizados para matar mamíferos terrestres e, em particular, porcos. O uso da zarabatana causa pouco sangramento na presa (que é morta não pelo ferimento mas pelo veneno) e implica maior distância entre caça e caçador, enquanto o uso de armas de perfuração causa intenso sangramento e uma relação menos mediada entre matador e vítima. Temos, pois, situações em que, diferentemente daquela descrita por Lima para os Juruna, a caça aos porcos parece ser positivamente marcada como uma predação de inimigos. Como interpretar este fato no quadro que vim até aqui delineando?

A saliência dos queixadas está associada ao fato de serem demasiadamente comida e demasiadamente humanos. É o mamífero menos proi- 
bido em toda a Amazônia — raros são os povos que o excluem de sua cozinha - , mas é também a caça que costuma exigir maior esforço de dessubjetivação, seja pela ação de xamãs, seja pela comensalidade por vezes ritualizada. Se a anta pode ocupar esse mesmo lugar (como parece ser o caso no Noroeste Amazônico), ela, no entanto, não tem costumes gregários, não envolve o mesmo esforço coletivo da caçada aos porcos e tampouco resulta na mesma quantidade de alimento. Daí por que sobre os porcos, mais do que sobre qualquer outro animal, recaia o imperativo moral de partilhar amplamente sua carne, cujo não cumprimento pode conduzir a estados mórbidos (Conklin 2001:163). Partilhar é, sobretudo, não se comportar como um predador solitário: o egoísmo alimentar é visto como uma deriva canibal, algo que os Guarani exprimem claramente ao aproximar o comportamento mesquinho ao do jaguar (H. Clastres 1975:113134). A comensalidade e a xamanização marcam, portanto, uma distância em relação ao canibalismo: mesmo sendo inimigos, não os comemos como inimigos, não desejamos sua parte-sujeito, mas sua parte-objeto.

A ambivalência dos porcos expressa-se, ainda, na maneira ritualizada em que podem ser consumidos, misturando-se os registros das duas modalidades de consumo (ontológica e alimentar). Os Huaorani do Equador distinguem a predação de animais arborícolas por meio da zarabatana (expressa pelo eufemismo "ir soprar") da caçada aos porcos realizada com lanças de guerra. Essa distinção dá ensejo, quando porcos são mortos, a uma festa orgiástica. Ao voltar ao acampamento, os caçadores colocam as mãos das crianças sobre a pele ainda palpitante e ensangüentada dos queixadas para que elas absorvam sua força e energia. A caça aos porcos, diz Rival, "é especial; é uma matança coletiva seguida de uma festa. [...] A carne dos porcos é considerada [...] extremamente intoxicante, e só pode ser consumida de modo infreqüente, em um tipo de orgia, pelo grupo huaomoni em cujo território a vara foi caçada." (1996:156)

Essa ambivalência do consumo de porcos que parece resvalar constantemente no canibalismo, obriga-nos a colocar uma última questão: o que dizer, então, da antropofagia?

\section{A comensalidade antropofágica}

Antes de responder a essa questão, permitam-me retomar o fio da meada. Até aqui argumentei que a distinção entre caça e guerra na Amazônia não é dada, em virtude da inexistência de uma barreira ontológica entre humanos e não-humanos, mas construída. Sugeri, em seguida, que 
há dois modos de produzir identidade e diferença por meio do comer: de um lado, come-se com e como alguém para identificar-se com esse alguém e produzir-se mutuamente como parente; de outro, come-se alguém para capturar algo deste alguém, sem no entanto se tornar inteiramente outro. Essas duas operações devem ser distinguidas prática e teoricamente, embora estejam articuladas em um mesmo movimento de reprodução social: a captura de algo de alguém abre caminho à familiarização, que se processa, entre outras coisas, pela comensalidade. Sugeri ainda que existem índices sensíveis, bem como práticas culinárias e rituais, que indexam essa distinção. Assim, por exemplo, a oposição entre cru e cozinhado (ou, em bemol, assado e cozido) é central para marcar a diferença entre canibalismo (comer alguém) e alimentação (comer com e como alguém).

Resta-nos enfrentar um último problema antes de concluir o texto. Eis a questão: a antropofagia é necessariamente uma prática canibal ou pode-se comer humanos como se fossem mera comida? Se, como vimos, há momentos em que certos animais são consumidos como inimigos (isto é, na sua condição de pessoa), é-nos legítimo perguntar se não há momentos em que os humanos são consumidos como simples comida (isto é, como objeto-inerte, suporte de outras relações). Vejamos.

Um dos elementos invariantes na antropofagia guerreira nas terras baixas da América do Sul é a disjunção entre matadores e comedores. Os homicidas não consomem a carne de suas vítimas, tendo, ao contrário, que dela se abster. Essa proibição estrita contrasta com a gama irrestrita de pessoas a quem é permitido comer um inimigo. Segundo os cronistas que descreveram o ritual antropofágico tupinambá, homens, mulheres, crianças e até bebês de colo deveriam fazê-lo. De modo idêntico, entre os Wari' de Rondônia, "qualquer pessoa, com exceção dos matadores, podia comer a carne de wijam [inimigo], inclusive as mulheres e crianças." (Vilaça 1992: 102). Havia, de um lado, uma proibição estrita (o matador jamais comia) e, de outro, uma liberalidade irrestrita (mesmo as crianças comiam).

A antropofagia guerreira tupinambá expressava-se na linguagem do desejo alimentar e da vingança. A carne humana era consumida porque doce e saborosa, e porque todos queriam ou deviam vingar-se do inimigo. O ato antropofágico definia um conjunto de posições relacionais. De um lado, produzia a aliança entre os que comiam juntos e a separação entre aqueles que eram, potencialmente, comida um do outro. De outro lado, o ato produzia os comedores enquanto predadores e a comida enquanto presa. Daí a célebre blague de Cunhambebe que, entre uma e outra mordidela na perna assada de um inimigo, teria respondido a Hans Staden, que 
o admoestava por comer seu semelhante, que ele, Cunhambebe, era um jaguar. Aquilo que o chefe tupinambá consumia não era, porém, a parte-predador do inimigo, pois esta quem devorara fora o matador recluso. A fração do inimigo que lhe cabia era, pois, sua parte-caça. Em outras palavras, tudo indica que os humanos eram aqui consumidos como se fossem simples comida e que, portanto, o repasto era um comer com e como alguém em que a subjetividade do objeto devorado estava ausente. Assim, conforme a definição que propus, a antropofagia tupinambá não era um canibalismo. Comia-se um corpo humano reduzido à condição de objeto, por meio do qual os comedores se identificavam entre si e produziam uma condição comum ${ }^{20}$. Não parece ser por outra razão que todos, mesmo as crianças, deveriam comer tudo.

Já o matador, pelo simples ato de matar, consumia outra coisa que a carne, detonando um processo de transformação, marcado publicamente pela reclusão. Mas o que era essa "outra coisa" ? Na literatura sobre guerra indígena na Amazônia, encontramos vários termos para designar o que se adquire ao matar um inimigo. Temos desde atributos corriqueiros como força e coragem, até categorias da filosofia e da psicologia, como subjetividade, atividade e intencionalidade, passando por conceitos metafísicos como espírito, sopro e alma. Esses termos traduzem categorias nativas que possuem em comum a idéia de que esse "algo" adquirido corresponde a uma capacidade que pertence ao outro (humano ou não-humano), que ao ser capturada por meio da predação, torna-se parte integrante da pessoa do predador como um suplemento. Esse suplemento pode ser concebido como um sujeito-outro que se funde ao matador, estabelecendo com ele uma relação assimétrica (é o caso araweté, por exemplo), ou como uma capacidade não hipostasiada em uma forma-sujeito, mas que implica a possibilidade futura de estabelecer relações assimétricas com sujeitos-outros (é o caso parakanã).

Gostaria de sugerir que, em ambos os casos, esse suplemento capturado corresponde à parte-predador do inimigo, ou, para nos aproximarmos dos conceitos nativos, sua parte-jaguar, que é destacável e pode ser transferida de um sujeito para outro. Para os Parakanã, por exemplo, o homicídio não conduz à apropriação de um espírito: o matador é simplesmente contaminado pelo odor de sangue e pela "gordura-mágica" (kawahiwa) da vítima, que lhe conferem uma capacidade predatória e criativa ${ }^{21}$. Esta capacidade está associada àquela de sonhar, por meio da qual se familiarizam inimigos que transferem cantos aos sonhadores. Estes cantos são denominados, eles mesmos, "jaguar" (jawara), e o sonhador é dito ser um "mestre dos jaguares" (jawajara). Ao oferecer um canto, o inimigo dá uma 
parte de si mesmo para o sonhador, sua parte-jaguar. Mas o que é uma parte-jaguar? Trata-se daquilo que permite a um sujeito, em uma relação com outro sujeito, determinar a direção do movimento da predação familiarizante.

O matador, em suma, por meio do ato homicida captura a parte-jaguar da vítima. O que resta, pois, aos comedores é uma outra parte, objetivada em um corpo, e em particular na sua carne, que poderíamos chamar de parte-caça, que é sua potência enquanto comida. Cada uma delas corresponde, assim, a uma das posições em uma relação de predação. Nem todos os seres, porém, possuem-nas em igual medida, pois a partição é indexada pela cadeia alimentar. Assim, o jaguar encontra-se em um pólo extremo, pois tudo nele remete à parte-predador; embora possua carne, ele não é visto como contendo uma parte-comida e, portanto, raramente é consumido para fins alimentares ${ }^{22}$. Isso talvez explique por que os Tupinambá realizavam um simulacro do ritual antropofágico utilizando o jaguar como vítima, mas, ao contrário do que faziam com o inimigo humano, não o comiam. Já os porcos, como vimos, possuem uma parte-comida nada negligenciável e, ao mesmo tempo, grande atividade. A separabilidade desses dois componentes se expressa na distinção entre o mestre dos porcos (ou o chefe da vara) e seus animais: o primeiro representa a parte-jaguar, enquanto os segundos, um coletivo anônimo, conotam o que há de passividade nos porcos. Aliás, os Piro afirmam explicitamente que o mestre dos porcos é o jaguar de sua espécie (Gow 2001: 69).

Em resumo, pode-se admitir que, na antropofagia guerreira, a distinção entre matadores e comedores corresponde àquela entre comer alguém e comer com e como alguém, e que, portanto, o ato de comer um humano era, antes de tudo, uma prática comensal. Consumia-se um corpo-outro para produzir-se como corpo de parentes.

Resta-nos agora saber se a mesma análise se aplica à antropofagia funerária. Nesta, costuma-se reencontrar a distinção entre os que comem e os que não comem, distinção que é recortada pelo parentesco, mas nem sempre da mesma maneira. Parece haver uma diferença, por exemplo, entre o consumo da carne e dos ossos do morto. Se, no primeiro caso, os parentes próximos não comem (enquanto os afins ou parentes distantes comem), no segundo, são os parentes do morto que costumam comer e controlar quem pode comer com eles. A distinção, no entanto, é bem mais complexa, pois alguns povos consumiam tanto a carne como os ossos do morto, e por vezes estabeleciam proibições e prescrições de natureza variada. Não posso aqui dar conta dessa variabilidade. Por isso, coloco-me uma única condição para que a análise sobre a antropofagia guerreira pos- 
sa ser estendida à funerária: é preciso, minimamente, que eu possa afirmar que a carne que se come é a parte-caça do parente morto.

É o que nos propõe Vilaça (2000) para o caso wari'. Os mortos eram consumidos como comida, uma assimilação expressa ritualmente em dois momentos: primeiro, quando os afins comiam o cadáver cortado e assado como caça; em seguida, no rito que encerrava o luto, quando todos, inclusive os parentes próximos, comiam caça animal como se esta fosse o cadáver humano. O trabalho do luto, realizado no intervalo entre o primeiro e o segundo momento do rito, permitia aos consangüíneos desfamiliarizar o morto e, assim, partilhar da visão dos afins, identificando-o à comida (Vilaça 2000:96), i.e., a um objeto que é suporte-inerte de outras relações. A antropofagia funerária wari' seria, pois, um comer como e com, mesmo sendo um humano o suporte da comensalidade. Daí a exigência de que todos os parentes do falecido estivessem presentes, inclusive aqueles distantes e habitando em outras aldeias, embora isto acarretasse com freqüência a putrefação do cadáver.

A distinção entre aqueles que comiam e os que não comiam não era, porém, da mesma ordem daquela existente na antropofagia guerreira. A abstinência dos parentes manifesta o processo de desfamiliarização de um morto-mesmo operada pelo complexo ritual, enquanto a do matador exprime um processo de familiarização de um morto-outro. Os movimentos são em direções opostas, mas correspondem a duas perspectivas de um mesmo processo, pois a desfamiliarização para uns corresponde à familiarização para outros. Se o funeral wari' cesurava as relações de parentesco construídas ao longo da vida, produzindo o esquecimento, ele permitia, ao mesmo tempo, a familiarização do morto por outra espécie de gente, já que ele era incorporado à espécie agressora responsável por sua morte ou ao mundo subaquático dos mortos (Vilaça 1992:61; Conklin 2001:166).

A identificação do cadáver à comida parece ter caracterizado também, como chamou a atenção Vilaça (2000), a antropofagia funerária de alguns povos pano (Dole 1962:570-571) e dos Guayaki (P. Clastres 1968). Nestes casos, havia uma ênfase no caráter alimentar do ato - a carne é saborosa, os que não a comem ficam magros — , bem como a noção de que todos, à exceção dos parentes próximos, podiam ou deviam comer o morto. Assim, por exemplo, entre os Guayaki, embora o consumissem geralmente assado, quando se tratava de uma criança pequena preferiam cozinhá-la para que houvesse "líquido suficiente para todo mundo" (P. Clastres 1968:39). Essa comensalidade funerária estendida era um índice decisivo para determinar as redes de aliança entre os diferentes bandos gua- 
yaki: grupos amigos deveriam ser convidados (ou deveriam receber uma parte do cadáver), sob pena de irem flechar "aqueles que os haviam esquecido." (P. Clastres 1968:40-41). Outra idéia que reencontramos no caso guayaki é a de que a antropofagia produzia ou favorecia a dissociação entre o corpo e a alma, uma noção que me parece referir-se à dupla operação de esquecer-se o morto e ser esquecido por ele, i.e., sua desfamiliarização aqui e sua familiarização alhures.

Os Kaxinawá, povo de língua pano, fornecem evidências suplementares para nossa análise. Conforme McCallum (1996:66), a antropofagia não era uma prática funerária universal, mas reservada a homens e mulheres de idade mais avançada, respeitados na comunidade, i.e., pessoas que encarnavam múltiplas relações de parentesco, constituindo-se em nós centrais da rede relacional (daí porque mortos sem parentes eram simplesmente enterrados). Ser comido era privilégio de alguns, mas comer, um dever de todos. A carne era aqui também consumida como caça. Ao oferecê-la aos convivas, o líder da cerimônia dizia: "Comam, comam, o filho da anta que à noite morreu" (McCallum 1996:67). Enquanto carne, ele podia servir à comensalidade entre parentes: "É como se o morto", afirma McCallum, "efetivamente fizesse um último ato constitutivo do parentesco. Em vez de oferecer carne de caça e peixe à comunidade [...] ele oferece seu próprio corpo" (1996:72). No entanto, trata-se da comensalidade entre parentes à exclusão do morto-parente, que deve ser esquecido, o nome apagado, a casa destruída, o caminho varrido.

Se a parte-caça do morto servia à produção do parentesco entre os vivos, a "alma do corpo" e a "alma do olho" deviam partir e constituir uma existência alhures, agora como um estrangeiro (um Nawa) - a primeira junto aos animais da floresta, a segunda junto ao Inka. Temos aqui um conjunto de correspondências reproduzidas em diferentes escalas: o corpo está para as almas, assim como a carne está para os ossos, assim como a "alma do corpo" está para a "alma do olho". O primeiro termo aparece como a parte-presa do segundo termo, parte-predador, como se cada pessoa contivesse em si várias relações de predação. Assim, se o festim da carne estava associado à liberação da "alma do corpo", o festim dos ossos estava associado à liberação da "alma dos olhos", ossos referidos pelo kaxinawá Pudicho Torres como "os ossos do Nawa, do homem poderoso, do homem do céu, do jaguar, do jiadama (gigante) [...]" (McCallum 1996:67)23.

Essa replicação de figuras da presa e do predador, objetivadas em partes distintas do corpo do morto e em diferentes escalas, pode ser reencontrada em outros contextos rituais onde não se praticava a antropofagia. Assim, por exemplo, os Jívaro utilizavam a cabeça do inimigo, sua 
parte-jaguar, como um objeto-sujeito; ao mesmo tempo, capturavam porcos que eram engordados, mortos e servidos aos convivas como substituto (imiak) do inimigo - i.e., da parte-caça do inimigo (Descola 1993:303). Contudo, essa partição não era simples, pois os porcos-vivos familiarizados não são a mesma coisa que os porcos-mortos cozidos, replicando a distinção mais geral entre a cabeça e os porcos (Fausto 2001:460). O mesmo princípio pode ser aplicado à escatologia. No caso pirahã, por exemplo, corpo e nome têm destinos distintos. Cada nome que um corpo recebeu em vida se divide, na morte, em dois componentes antagônicos, kaoaiboge e toipe, que representam grosso modo a parte-presa e a parte-predador da pessoa (ou uma capacidade gregária e sociável em oposição a outra guerreira e canibal). Os toipe vivem querendo predar os kaoaiboge, que podem sofrer até duas mortes, mas na terceira transformam-se em jaguar; já os toipe quando mortos pela primeira vez viram um super-toipe, mas se forem mortos de novo tornam-se um kaoaiboge, que então segue seu destino de presa até virar jaguar (Gonçalves 2001:204-205).

A complexidade de cada exemplo etnográfico mereceria uma análise cuidadosa que aqui não posso fazer. Minha leitura da antropofagia não deve, pois, ser confundida com uma análise dos ritos antropofágicos. Há muito mais a dizer sobre eles, a começar sobre as inversões das posições de presa e predador e sobre as formas complexas pelas quais as relações são postas em ação. Dito isso, porém, insisto que é possível afirmar — e isto é o bastante para os objetivos deste texto - que na antropofagia a carne do morto humano é consumida como comida, que há uma disjunção entre predação ontológica e comensalidade, e que essa disjunção se ergue sobre a possibilidade de separar a pessoa humana em uma partepredador e uma parte-presa, ou, se quiserem, em uma parte-ativa e outra passiva, indexada freqüentemente, mas não exclusivamente, pela relação de predação.

\section{A moral do canibal}

Ao longo deste texto, afastei-me progressivamente da formulação corrente de que os animais e vegetais também são pessoas, formulação esta que estabelece uma equivalência, no contexto das relações entre humanos e não-humanos, entre pessoa e parte-ativa ou essência antropomórfica de plantas e animais. Preferi tratar a pessoa como um amálgama de atividade e passividade, como alguém que contém em si as duas perspectivas possíveis de uma relação de predação. A passagem da potência ao ato, 
da tensão à ação predatória, é o que produziria a disjunção dessas perspectivas na forma de "partes". Procurei chamar a atenção também, embora sem elaborar devidamente, que essa partição não é simples, mas complexa, pois replicável em diferentes escalas e sujeita a inversões e condensações. Uma análise cerrada de certos rituais iluminaria esse tipo de complexidade, digamos, fractal, que é congênita ao modelo da socialidade amazônica recentemente proposto por Viveiros de Castro (2001) (ver, também, Kelly Luciani 2001).

Minha tentativa de reconceitualizar o dualismo corpo e alma teve como ponto de partida a proposição de Brightman para o caso algonquino da floresta boreal. Sua questão inicial é a mesma que a minha e de outros amazonistas (Descola 1998; Hugh-Jones 1996): em ontologias em que tanto humanos como animais são pessoas, como diferenciar o consumo da caça do canibalismo? Como vimos, sua resposta consistia, por um lado, em postular a distinguibilidade entre corpo zoomorfo e alma antropomórfica, e, por outro, em adotar a idéia dominante de que o canibalismo se define como consumo do semelhante. Na medida em que a similitude entre animais e humanos se dá no plano da alma, comer o corpo da presa não seria uma forma de canibalismo. Neste artigo, afastei-me dessa noção e busquei redefinir o canibalismo como consumo da parte-ativa do outro. Em seguida, procurei mostrar que, se a formulação de Brightman em termos do dualismo corpo e alma é econômica, ela leva a uma simplificação indevida dos materiais etnográficos. Ao dizer que não há um dualismo simples, não estou afirmando que inexistam distinções entre componentes mais ou menos materiais, mais ou menos representacionais, mais ou menos relacionais que constituem a pessoa humana e não-humana. Contudo, tais distinções não estão organizadas por um dualismo global, seja porque as almas são múltiplas, seja porque o corpo não é uma unidade discreta, seja porque a alma tem corpo e certas partes do corpo têm mais alma do que outras, ou ainda porque o corpo não contém nenhuma alma dentro de si, sendo a presença da alma a manifestação da ausência do corpo.

Tampouco a distinção entre roupa-animal e essência-humanóide parece aplicar-se bem à Amazônia. De um lado, muitas das capacidades agentivas e subjetivas que conferem intencionalidade e potência aos humanos encontram-se privilegiadamente em alguns animais, em especial nos predadores (e, dentre estes, naqueles que possuem "desenho", como o jaguar e a anaconda). De outro, os humanos também possuem uma pele-roupa que os diferencia de outros tipos de seres (sejam animais ou inimigos), e que pode ser decorada, vestida ou mesmo trocada. Essas "pe- 
les" ou "roupas" representam, muitas vezes, a parte-ativa da pessoa, seu suplemento de beleza e de capacidade agentiva. Eis por que, por exemplo, os Barasana queimam as penas e pêlos dos animais que querem dessubjetivar para que sirvam de alimento, e usam-nas como ornamentos quando querem se apropriar do "poder potencialmente perigoso de suas 'armas'" (Hugh-Jones 1996:141). O corpo zoomorfo não é, assim, uma unidade monolítica, substrato mecânico habitado por uma essência humanóide. Cada uma de suas partes, e em diferentes medidas, é um "edifício de almas múltiplas".

Para evitar, pois, a oposição simples entre corpo e alma (ou entre aparência-animal e essência-humana), propus a distinção entre um consumo do outro na condição de sujeito e seu consumo na condição de objeto. Essa distinção, porém, é dinâmica e complexa, pois supõe que cada sujeito do cosmos possui, em proporções próprias à sua espécie e condição, uma potência positiva para ocupar a posição de agente e outra negativa para ocupar a de paciente em uma relação de predação. Essa dupla potência é interna ao sujeito e constitutiva de sua condição específica; ele é, por assim dizer, um amálgama de predador e de presa. Quando se estabelece uma interação predatória de dois sujeitos assim constituídos, define-se uma meta-relação na qual um dos sujeitos ocupa a posição ativa e o outro a passiva. O ato predatório, porém, não eclipsa a constituição dual do sujeito; ao contrário, manifesta-a por meio de uma fratura que pode conduzir a dois tipos de consumo: de um lado, aquele próprio à guerra e ao canibalismo, no qual se consome a parte-predador da vítima; de outro, aquele característico da cozinha alimentar, no qual se consome a partepresa da vítima.

Essas modalidades, porém, exigem trabalho suplementar, pois em ambos os casos há o risco de reversão de posições. De um lado, ao consumir a parte-predador da presa, o guerreiro corre o risco de tornar-se ele mesmo uma presa - por isso, ao homicídio, segue-se o resguardo no qual a parte-predador da presa é feita parte-predador do predador ${ }^{24}$. De outro, o ato predatório não faz da caça imediatamente um objeto-inerte - é preciso continuar a desconstituir o sujeito, retirando progressivamente a atividade nele contida por meio de uma série de operações xamânicas e culinárias. Esse processo de objetificação reduz a presa à condição de comida, que serve para produzir os corpos dos parentes e o corpo de parentes, isto é, a socialidade do parentesco (Vilaça 1999).

Ao contrário do jaguar, temível predador solitário, os humanos possuem recursos para distinguir a alimentação cotidiana do canibalismo. Daí a importância do fogo culinário nos mitos analisados por Lévi-Strauss 
em Le Cru et le Cuit (1964). Esses mitos não falam da instauração de uma ruptura definitiva entre cultura e natureza, mas sim da constituição de dois códigos predatórios, o do jaguar e o dos humanos, que faz do primeiro um mestre entre mestres e permite aos segundos produzir o parentes$\mathrm{Co}^{25}$. O fogo culinário torna possível a alimentação carnívora não-canibal, permitindo aos parentes produzirem-se como parentes. Se só consumissem animais-agentes terminariam por ou bem identificar-se com eles (tornando-se um deles), ou bem por não reconhecer outra forma de relação além da devoração. Eis por que alguns caçadores não comem sua própria presa, ou não a transportam, ou evitam certas partes como a cabeça. Eles querem continuar a ser humanos, provendo de carne suas esposas, filhos e afins. Daí por que a generosidade e a moderação são indexadores básicos da aceitação do parentesco, enquanto a gula e o egoísmo são associados ao feiticeiro, ao jaguar e à solidão.

A questão ética na Amazônia parece, assim, incidir antes sobre as relações entre os parentes do que sobre as relações entre humanos e animais. Mesmo porque não se trata de excluir o canibalismo, não há ruptura definitiva entre o código predatório do jaguar e aquele dos humanos. Trata-se, isso sim, de tornar o canibalismo não excessivo, mediatizado por especialistas e praticado em ocasiões rituais. Se assim não fosse, a predação canibal tornar-se-ia a medida das relações interiores e não haveria produção do parentesco. Seríamos todos só jaguares e isto só alguns deuses o são.

Recebido em 10 de março de 2002

Aprovado em 5 de julho de 2002

Carlos Fausto é professor do PPGAS, Museu Nacional/UFRJ, e pesquisador do CNPq. É autor de Os Índios Antes do Brasil (2000) e de Inimigos Fiéis: História, Guerra e Xamanismo na Amazônia (2001). 


\section{Notas}

* Uma primeira versão deste artigo foi apresentada na École des Hautes Études en Sciences Sociales, em 2001. Agradeço a Philippe Descola pelo convite e comentários, que me auxiliaram a precisar a análise, e à CAPES pela bolsa de pósdoutorado. Agradeço também a Jean-Pierre Goulard, Dimitri Karadimas, JeanPierre Chaumeil, Isabelle Daillant, Marcia Damaso e Carolina P. de Araújo pelas idéias e dados que compartilharam comigo. Sou grato a Marcela Coelho de Souza, Federico Neiburg e Steve Hugh-Jones pela leitura do manuscrito e pelos comentários valiosos que fizeram. Steve ofereceu-me ainda vários dados sobre o Noroeste Amazônico. Finalmente, agradeço a Aparecida Vilaça que me influenciou decisivamente na concepção deste texto, tanto na formulação do problema, como nas respostas que forneço. A responsabilidade pelos erros e desvios de rota é do autor.

1 Refiro-me aos trabalhos de Overing $(1991 ; 1999)$ e de seus ex-estudantes, formados na London School of Economics na década de 80, em especial Gow (1991), McCallum (2001), Belaunde (2001) e Santos-Granero (1991).

2 Vilaça (1992:292) colocou-se essa questão no final de seu livro e forneceu respostas pontuais em textos subseqüentes $(1999 ;$ 2000; 2002). A discussão que aqui desenvolvo busca alinhavar vários de seus argumentos com o fio da "predação familiarizante" (Fausto 1999a; 2001).

3 Para rejeitar a identificação entre caça e guerra, P. Clastres vale-se de um argumento irônico. Ele parte de uma proposição característica dos materialistas e chega a uma conclusão que lhes seria inaceitável: “[...] se a guerra é caça então a guerra é a caça ao homem. A caça deveria então ser a guerra aos bisões, por exemplo." (1982:176). A conclusão, porém, só é inaceitável se a equivalência entre caça e guerra for traçada pelo lado da natureza, e não da cultura.

4 Sobre a aquisição de bens por animais, ver Brightman (1993:163); para exemplo semelhante na Amazônia, ver Conklin (1995:97).

5 O modelo benévolo convive com outro esquema relacional, que Brightman denomina adversativo, no qual a caça se manifesta como violência mascarada. Esse segundo modelo se coaduna com uma noção mais geral que associa a capacidade predatória ao poder; a cadeia alimentar funciona como "índice pragmático do poder relativo de diferentes seres, [dispostos] em uma hierarquia intransitiva" (Brightman 1993:197). Esse modelo adversativo, indexado pela relação predadorpresa, seria minoritário no contexto boreal.

6 Um mito cree, que narra uma caçada da perspectiva de um jovem humano casado com uma fêmea caribu, ilustra essa concepção: "Os seres humanos vêem os caribus correndo dos caçadores, e quando um deles é alvejado, o animal cai e 
morre; mas o jovem, assistindo ao mesmo evento, vê uma pessoa fugindo, vestida em uma capa branca, que ela joga fora e que o caçador pega como o animal morto." (Tanner 1979:137). Compare-se com uma narrativa amazônica (yaminawa) em que a dupla perspectiva de um caçador desafortunado, que fora adotado por uma vara de porcos e recuperado por seus irmãos humanos, serve à predação. $\mathrm{O}$ homem-porco lidera uma caçada contra seus ex-parentes-porcos, apontando os animais e dizendo: "esse era meu sogro, dispara!", "essa era minha mulher, dispara!" (Calavia Sáez 2001:163).

7 Sobre a noção de comunidade de abstinência, ver Viveiros de Castro (1992:192) e Rival (1999:65).

8 A conexão entre a noção de familiarização e o universo alimentar é explícita entre os Barasana. Segundo Hugh-Jones (inf. pessoal), o verbo ekaa-re significa tanto "alimentar" como "domesticar", e os xerimbabos são denominados ekariera, "aqueles que alimentamos". O verbo ekaa-re, "dar comida", distingue-se de isi-re, "dar" e de waha yi-re, "trocar, vender", implicando justamente a noção de domesticar, amansar, familiarizar (algo que se aplica também à oferta cerimonial de comida e à comensalidade entre afins no ritual).

9 A reversão desse processo também pode ser pensada como reinstituição dos laços de comensalidade. Entre os Asurini do Tocantins, a ressurreição de um xamã passa pelo oferecimento de mingau doce de palmito para seu espírito, que deve bebê-lo, noite após noite, até acostumar-se novamente aos vivos e voltar à vida a partir dos ossos (Andrade 1992:220-222).

${ }^{10}$ Remeto o leitor aos exemplos arquinotórios sobre o homicídio guerreiro e a devoração dos mortos por deuses ou animais, que bem ilustram esse tipo de operação identificatória por englobamento.

${ }^{11}$ Há vários elementos que podem servir como índice de potência subjetiva, como a longevidade (Lagrou 1998:41; Harner 1978:138), a capacidade de vocalização, o comportamento matrimonial de certas espécies (Descola 1998:27) e assim por diante. A quantidade e a cor do sangue são também índices importantes de capacidade transformativa, prestando-se a justificar interditos e preferências alimentares, como ocorre entre os Pirahã, que distinguem os animais em três categorias de comestibilidade segundo esses critérios (Gonçalves 2001:359).

12 As técnicas mais radicais são anticulinárias: a incineração que reduz a capacidade transformativa (daí por que utilizada comumente contra feiticeiros, xamãs e missionários) e a putrefação que, ao contrário, intensifica a tensão transformativa (ver Lagrou 1998:38-39).

13 Os Cree parecem ter praticado o canibalismo nas guerras contra os Inuit no século XVIII, comendo pedaços de carne crua do inimigo. Brightman (1993:142) relaciona essa prática a uma outra, de caça, que consiste em beber o sangue fresco do caribu ou do alce. 
14 Ver, por exemplo, Smith (1998) que insiste à exaustão no caráter monista da ontologia atapascana.

15 Essa idéia de captura pode ser apenas um modelo geral abstrato, ou ser particularizada para cada nascimento. Entre os Parakanã, temos ambas as situações. Diz-se que os princípios vitais despersonalizados entram pela vagina das mulheres, quando elas se banham no rio. Mas há algumas pessoas que são ditas serem filhas da waratoa (o bastão rítmico usado no ritual de mesmo nome), que captura futuras crianças e as insere nas mulheres. Há outras que são ditas serem filhas de algum animal, pois um evento durante uma caçada pode ser a origem da gravidez (assim, no caso de um menino que é filho de paca, a mãe se viu grávida após o animal passar, em fuga, entre suas pernas e desaparecer).

${ }^{16}$ Em mbyá guarani, o-jepo-ta significa "transformar-se em". Assim, "o homem transformou-se em onça" (ou "virou onça") diz-se "ava o-je-pota xivi-re" (Damaso inf. pessoal). Sobre esse exemplo, ver, também, Vilaça (2002:363).

17 Entre os Parakanã, o matador deve abrir mão de suas armas. Sua irmã irá pedir-lhe que dê o arco ao cunhado, a fim de que este possa trazer carne de caça para ela (não se trata, porém, do arco com que perpetrou o homicídio). Ele fornece, assim, o instrumento para que o afim continue a satisfazer o desejo de sua irmã de comer carne, reconhecendo a relação que os une. Por vezes, contudo, o inimigo faz o matador "perder a consciência" (-pikajym) e voltar-se contra os próprios parentes.

18 Esse argumento não dá conta das numerosas restrições alimentares cuja explicação nativa remete à transferência de uma característica do alimento à pessoa reclusa, sem recorrer à qualquer capacidade agentiva do animal ou da planta. Os Parakanã, por exemplo, estabelecem apenas uma relação analógica entre qualidades do alimento ingerido e seu efeito no matador em resguardo (se comer cará ficará com as nádegas estreitas, se comer caititu seus testículos crescerão, e assim por diante). Essas proibições remetem a uma operação mais geral: a transferência analógica de qualidades de um ser para outro, que é básica do simbolismo ritual. A mesma operação explica por que, após o homicídio, o matador parakanã deve sentar-se sobre uma pedra (para tornar-se rijo e longevo) ou o dançarino no festival do tabaco deve ter as pernas cobertas de plumas de harpia. Se o complexo de interdições remete a uma operação analógica bem mais geral que a hipótese animista ou perspectivista, gostaria de sugerir, no entanto, que os exemplos citados acima são, no contexto amazônico, casos bemóis de alteração, nos quais uma parte do corpo se transforma no animal ou vegetal consumido.

${ }^{19}$ Nesses casos, temos vegetais consumidos como se fossem animais predadores. Seria preciso refletir também sobre os vegetais domesticados, pois a horticultura costuma representar uma socialidade segura voltada para o interior e distinta da socialidade predatória da caça voltada para o exterior (Fausto 2001:514515). Seria desejável, ainda, incorporar à discussão um outro elemento do sistema: a cerveja, normalmente feita de vegetais domesticados, cuja fermentação po- 
de equivaler a um processo de subjetivação (veja-se, por exemplo, o caso juruna em Lima 1995).

20 A socialização do ato homicida (i.e., da predação ontológica) dava-se em outro momento do ritual. Como apontei alhures (Fausto 1999b:270-271), entre os Tupinambá, as mulheres podiam beneficiar-se da predação ontológica e ser renomeadas por meio da participação nos eventos que precediam à execução, como a recaptura simbólica do cativo. O mesmo ocorria com as mulheres nivacle, que dançavam com o escalpo-troféu ainda ensangüentado para que "um pouco da almaespírito da vítima" passasse para elas (Sterpin 1993:42).

${ }^{21}$ Isto, porém, só ocorre quando se mata um homem adulto. Crianças não têm "gordura-mágica", e mulheres têm-na escassamente. O assassinato de uma mulher não produz o estado de enfurecimento criativo que conduz o matador a novas predações ontológicas, mas apenas "faz ter fome", levando-o a ser mesquinho com os parentes. Ele se torna um jaguar em bemol, pois não partilhar a caça, como disse, é um comportamento associado ao felino e oposto à comensalidade entre parentes.

22 A língua muinane da Colômbia, rica em classificadores nominais, parece refletir essa concepção. O classificador -gai, que se aplica a todos os seres animados, jamais é afixado aos termos "jaguar" (hwku) e "cacique" (ke?é?i), como se estes fossem exemplares não-marcados dessa classe, os protótipos de animação (Vengoechea 2001).

${ }^{23}$ No Alto Rio Negro, o consumo de ossos calcinados parece também ter essa mesma conotação, pois eles representam a parte-predador da pessoa, estando associados aos ancestrais, às flautas jurupari, ao jaguar e à anaconda (Hugh-Jones, inf. pessoal).

${ }^{24}$ Como sugeri alhures, o esquema mais comum para se pensar esse acúmulo de potência predatória é o da relação senhor-xerimbabo.

${ }^{25}$ Notem que os mitos jê insistem no fato de que o jaguar é completamente despossuído do fogo que lhe pertencera: mesmo as brasas que caem no caminho durante a fuga são cuidadosamente recuperadas ou extintas. Note-se, ainda, que a versão wari' desse mito faz do fogo culinário um fogo funerário: os humanos definem-se como comedores de parentes mortos assados. 


\section{Referências bibliográficas}

ALBERT, Bruce. 1985. Temps du Sang, Temps des Cendres: Représentation de la Maladie, Système Rituel et Espace Politique chez les Yanomami du Sud-Est (Amazonie Brésilienne). Tese de Doutorado, Université de Paris-X (Nanterre).

ANDRADE, Lucia M. M. de. 1992. O Corpo e o Cosmos: Relações de Gênero e o Sobrenatural entre os Asurini do Tocantins. Dissertação de Mestrado, Universidade de São Paulo.

ÅRHEM, Kaj. 1996. "The Cosmic Food Web: Human-Nature Relatedness in the Northwest Amazon". In: P. Descola e G. Pálsson (orgs.), Nature and Society: Anthropological Perspectives. London: Routledge. pp. 185-204.

BELAUNDE, Luisa Elvira. 2001. Viviendo Bien: Género y Fertilidad entre los Airo-Pai de la Amazonía Peruana. Lima: CAAP.

BIRD-DAVID, Nurit. 1990. "The Giving Environment: Another Perspective on the Economic System of Gatherer-Hunters". Current Anthropology, 31:189-196.

BRIGHTMAN, Robert A. 1993. Grateful Prey: Rock Cree Human-Animal Relationship. Berkeley: University of California Press.

CAlaVia SÁEZ, Oscar. 2001. “El Rastro de los Pecaríes: Variaciones Míticas, Variaciones Cosmológicas y Indentidades Étnicas en la Etnología Pano". Journal de la Société des Américanistes, 87:161-176.

CHAUMEIL, Jean-Pierre. 1983. Voir, Savoir, Pouvoir: Le Chamanisme chez les Yagua du Nord-Est Péruvien. Paris: École des Hautes Études en Sciences Sociales.
CLASTRES, Hélène. 1975. La Terre Sans Mal: Le Prophétisme Tupi-Guarani. Paris: Seuil.

CLASTRES, Pierre. 1968. "Ethnographie des Indiens Guayaky". Journal de la Société des Américanistes, LVII:8-61. .1982. Arqueologia da Violência: Ensaios de Antropologia Política. São Paulo: Brasiliense.

CONKLIN, Beth. 1995. "Thus Are Our Bodies, thus Was Our Custom': Mortuary Cannibalism in an Amazonian Society". American Ethnologist, 22 (1):75-101.

.2001. Consuming Grief: Compassionate Cannibalism in an Amazonian Society. Austin: University of Texas Press.

DESCOLA, Philippe. 1986. La Nature Domestique: Symbolisme et Praxis dans l'Écologie des Achuar. Paris: Maison des Sciences de l'Homme. . 1992. "Societies of Nature and the Nature of Society". In: A. Kuper (org.), Conceptualizing Society. London: Routledge. pp. 107-126.

. 1993. Les Lances du Crépuscule: Relation Jivaros. Haute Amazonie. Paris: Plon. . 1998. "Estrutura ou Sentimento: A Relação com o Animal na Amazônia". Mana, 4(1):23-45.

DOLE, Gertrude. 1962. "Endocannibalism among the Amahuaca Indians". Transactions of the New York Academy of Sciences, 24(5):567-573.

ERIKSON, Philippe. 1986. "Alterité, Tatouage et Anthropophagie chez les Pano: La Belliqueuse Quête de Soi". Journal de la Société des Américanistes, LXII:185-210.

FAUSTO, Carlos. 1999a. "Of Enemies and Pets: Warfare and Shamanism 
in Amazonia". American Ethnologist, 26(4):933-956.

. 1999b. "Da Inimizade: Forma e Simbolismo da Guerra Indígena". In: A. Novaes (ed.), A Outra Margem do Ocidente. São Paulo: Companhia das Letras. pp. 251-282.

.2001. Inimigos Fiéis. História, Guerra e Xamanismo na Amazônia. São Paulo: EDUSP.

.no prelo. "A Blend of Blood and

Tobacco: Shamans and Jaguars among the Parakanã of Eastern Amazonia". In: N. Whitehead e R. Wright (eds.), Dark Shamans: The Anthropology of Assault Sorcery in Amazonia. Chapell Hill, NC: Duke University Press.

GIRALDO-FIGUEROA, Alba Lucy. 1997. Guerriers de l'Écriture et Commerçants du Monde Enchanté: Histoire, Identité et Traitment du Mal chez les Sateré-Mawé (Amazonie Centrale, Brésil). Tese de Doutorado, École des Hautes Études en Sciences Sociales.

GONÇALVES, Marco Antonio. 2001. O Mundo Inacabado: Ação e Criação em uma Cosmologia Amazônica. Etnografia Pirahã. Rio de Janeiro: Editora da UFRJ.

GOULARD, Jean-Pierre. 1998. Les Genres du Corps: Conceptions de la Personne chez les Ticuna de la Haute Amazonie. Tese de Doutorado, École des Hautes Études en Sciences Sociales.

GOW, Peter. 1991. Of Mixed Blood: Kinship and History in Peruvian Amazonia. Oxford: Clarendon Press. . 1997. "O Parentesco como Consciência Humana". Mana, 3(2):39-65. . 2001. An Amazonian Myth and its History. Oxford: Oxford University Press.

GRAY, Andrew. 1996. The Arakmbut: Mythology, Spirituality, and History in an Amazonian Community. Providence, RI: Bergham Books.

. 1997. The Last Shaman: Change in an Amazonian Community. Providence, RI: Bergham Books.

GREGOR, Thomas. 1990. “Uneasy Peace: Intertribal Relations in Brazil's Upper Xingu". In: J. Haas (ed.), The Anthropology of War. Cambridge: Cambridge University Press. pp. 105-124.

HARNER, Michael. 1973. Hallucionogens and Shamanism. Oxford: Oxford University Press.

.1978. Shuar: Pueblo de las Cascadas Sagrada. Quito: Ediciones Mundo Shuar.

HUGH-JONES, Stephen. 1996. “Bonnes Raisons ou Mauvaise Conscience? De l'Ambivalence de Certains Amazoniens envers la Consommation de Viande". Terrains, 26:123-148.

INGOLD, Tim. 2000. The Perception of the Environment: Essays on Livelihood, Dwelling and Skill. London: Routledge.

KARADIMAS, Dimitri. 1997. Le Corps Sauvage. Idéologie du Corps et Représentations de l'Environnement chez les Miraña d'Amazonie Colombienne. Tese de Doutorado, Université de Paris X (Nanterre).

KELLY LUCIANI, José Antonio. 2001. "Fractalidade e Troca de Perspectivas". Mana, 7(2):95-132.

KENSINGER, Kenneth. 1975. The Cashinahua of Eastern Peru. Providence, RI:The Haeffenreffer Museum of Anthropology, Brown University.

LAGROU, Elsje. 1998. Cashinahua Cosmovision: A Perspectival Approach to Identity and Alterity. Tese de Doutorado, University of St. Andrews.

LÉVI-STRAUSS, Claude. 1964. Le Cru et le Cuit. Mythologiques I. Paris: Plon. _.1965. "Le Triangle Culinaire". $L^{\prime} A r c$, 26:19-29. 
LIMA, Tânia Stolze. 1995. A Parte do Cauim. Etnografia Juruna. Tese de Doutorado, PPGAS/Museu Nacional/ UFRJ.

. 1996. "O Dois e seu Múltiplo: Reflexões sobre o Perspectivismo em uma Cosmologia Tupi". Mana, 2(2): 21-47.

MCCALluM, Cecilia. 1996. "Morte e Pessoa entre os Kaxinawá". Mana, 2(2):49-84.

-.2001. Gender and Sociality in Amazonia: How Real People Are Made. Oxford: Berg.

OAKDALE, Suzanne. 1998. The Power of Experience: Agency and Identity in Kayabi Healing and Political Process in the Xingu Indigenous Park. Tese de Doutorado, University of Chicago.

OVERING (KAPLAN), Joanna. 1975. The Piaroa: A People of the Orinoco Basin. Oxford: Clarendon Press. . 1991. “A Estética da Produção: O Senso de Comunidade entre os $\mathrm{Cu}$ beo e os Piaroa". Revista de Antropologia, 34:7-33.

_ . 1999. "Elogio do Cotidiano: A Confiança e a Arte da Vida Social em uma Comunidade Amazônica". Ma$n a, 5(1): 81-107$.

REICHEL-DOLMATOFF, Gerardo, 1973. Desana: Le Symbolism Universel des Indiens Tukano du Vaupés. Paris: Gallimard.

RIVAL, Laura. 1996. "Blowpipes and Spears: The Social Significance of Huaorani Technological Choices". In: P. Descola e G. Pálsson (orgs.), Nature and Society: Anthropological Perspectives. London: Routledge. pp. 145-164.

. 1999. "Prey at the Center: Resistance and Marginality in Amazonia". In: S. Day, E. Papataxiarchies e M. Stewart (eds.), Lilies of the Field: Marginal People who Live for the
Moment. Boulder, CO: Westview Press. pp. 61-79.

SANTOS-GRANERO, Fernando. 1991. The Power of Love: The Moral Use of Knowledge amongst the Amuesha of Central Peru. London: Athlone.

SCHADEN, Egon. 1954. "Aspectos Fundamentais da Cultura Guaraní". Boletim da FFCL, 188 (Antropologia 4), Universidade de São Paulo.

SISKIND, Janet. 1973. To Hunt in the Morning. Oxford: Oxford University Press.

SMITH, David M. 1998. "An Athapaskan Way of Knowing: Chipewyan Ontology". American Ethnologist, 25(3): 412-432.

STERPIN, Adriana. 1993. "La Chasse aux Scalps chez les Nivacle du Gran Chaco". Journal de la Société des Américanistes, LXXIX:33-66.

STRATHERN, Marilyn. 1988. The Gender of the Gift: Problems with Women and Problems with Society in Melanesia. Berkeley: University of California Press.

TANNER, A. 1979. Bringing Home Animals: Religious Ideology and Mode of Production of the Mistassini Cree Hunters. London: Hurst.

TAYLOR, Anne-Christine. 2000. "Le Sexe de la Proie. Répresentation Jivaro du Lien de Parenté". L'Homme, 154155:309-334.

. s/d. "Sick of History. Contrasting Regimes of Historicity in the Upper Amazon". In: C. Fausto e M. Heckenberger (orgs.), Time Matters: History and Historicity in Amazonia (em preparação).

VENGOECHEA, Consuelo. 2001. Classificación Nominal el la Lengua Muinane. Comunicação apresentada no Centre d'Études des Langues Indigènes Amerindiennes (CELIA), Paris, novembro.

VILAÇA, Aparecida. 1992. Comendo co- 
mo Gente: Formas do Canibalismo Wari'. Rio de Janeiro: Editora da UFRJ.

.1999. "Devenir Autre: Chamanisme et Contact Interethnique en Amazonie Brésilienne". Journal de la Société des Américanistes, 85: 239-260.

.2000. "Relations between Funerary Cannibalism and Warfare Cannibalism: The Question of Predation". Ethnos, 65(1):84-106.

. 2002. "Making Kin Out of Others". Journal of the Royal Anthropological Institute, 8(2):347-365.

VIVEIROS DE CASTRO, Eduardo. 1992. From the Enemy's Point of View: Humanity and Divinity in an Amazonian Society. Chicago: Chicago University Press.

. 1996. "Os Pronomes Cosmológicos e o Perspectivismo Ameríndio". Mana, 2(2):115-144.

. 2001. "GUT Fellings about Amazonian: Potential Affinity and the Construction of Sociality". In. L. Rival e N. Whitehead (orgs.), Beyond the Visible and the Material. Oxford: Oxford University Press. pp. 19-44. 


\section{Resumo}

Partindo da noção de predação familiarizante, este artigo visa discutir a relação entre canibalismo e comensalidade na Amazônia, tomando-os como formas diferenciadas, mas articuladas, de consumo. Começa-se por uma análise da relação entre guerra e caça em ontologias que atribuem aos animais a condição de pessoa. Discute-se o encadeamento dos ciclos de predação de humanos e animais por meio das concepções de doença e de resguardo. Argumenta-se que a comensalidade é um vetor de identificação que opera sobre um objeto, a comida, que deve ser produzido enquanto tal para que os parentes não se identifiquem ao animal consumido. Analisamse os mecanismos de dessubjetivação da presa e argumenta-se que eles se erguem sobre a partibilidade das pessoas, a qual não deve ser reduzida a um dualismo simples e global entre corpo e alma. Sugere-se uma outra leitura para esse fato e se a aplica, por fim, à antropofagia guerreira e funerária.

Palavras-chave Amazônia, Animismo, Caça, Canibalismo, Parentesco

\section{Abstract}

Taking the notion of familiarizing predation as a starting point, the article sets out to articulate two forms of consumption in Amazonia: cannibalism and commensality. It begins by analyzing the relationship between war and hunting in ontologies that attribute the condition of persons to animals. The interlocking of the human and animal predatory cycles is made manifest by the analysis of indigenous practices concerning illness, seclusion and food taboos. The article explores then the idea that commensality is a vector of identification for the production of kinship. As such it presupposes the transformation of the animal prey into an object, in order to block the identification of the eater with the thing consumed. The practices for de-subjectifying the prey are analyzed, bringing forth the argument that they are based on a specific conception about the partibility of the person, one which shall not be reduced to a simple and global body and soul dualism. The article offers a different rendering of this partibility, shedding new light on warfare and funerary anthropophagy in Amazonia.

Key words Amazonia, Animism, Hunting, Cannibalism, Kinship 